\title{
KARAKTERISTIK MATRIKS SEBAGAI DAERAH ASAL SUATU FUNGSI LOGARITMA
}

\author{
Era Dewi Kartika \\ IKIP Budi Utomo Malang \\ erfolgera@gmail.com
}

\begin{abstract}
Abstrak
Rumus umum fungsi logaritma asli dengan daerah asal suatu matriks adalah

$$
\begin{aligned}
\ln A=T S_{\left(J_{A}\right)} \ln & \left(\lambda_{1} I^{\left(p_{1}\right)}\right. \\
& \left.+H^{\left(p_{1}\right)}\right), \ln \left(\lambda_{2} I^{\left(p_{2}\right)}+H^{\left(p_{2}\right)}\right), \ldots, \ln \left(\lambda_{u} I^{\left(p_{u}\right)}\right. \\
& \left.\left.+H^{\left(p_{u}\right)}\right)\right\} S_{\left(J_{A}\right)}{ }^{-1} T^{-1}
\end{aligned}
$$

dengan $T$ adalah matriks non-singular dimana $A=T J_{A} T^{-1}, S_{\left(J_{A}\right)}$ adalah sebarang matriks yang komutatif dengan $J_{A}, J_{A}$ adalah matriks Jordan dari matriks $A, \lambda_{i}$ adalah nilai karakteristik dari pembagi elementer $A, I$ adalah matriks identitas dan $H^{(p)}$ adalah matriks berukuran $p \times p$ yang mempunyai 1 sebagai anggota pada superdiagonal pertama dan 0 untuk lainnya. Karakteristik matriks $A$ sebagai daerah asal suatu fungsi logaritma adalah matriks persegi yang non-singular dengan nilai-nilai karakteristik real positif
\end{abstract}

Kata Kunci: matriks, daerah asal, logaritma asli

\begin{abstract}
The general formula of the natural logarithm function with domain of a matrix is

$$
\begin{aligned}
\ln A=T S_{\left(J_{A}\right)}\{ & \ln \left(\lambda_{1} I^{\left(p_{1}\right)}\right. \\
& \left.+H^{\left(p_{1}\right)}\right), \ln \left(\lambda_{2} I^{\left(p_{2}\right)}+H^{\left(p_{2}\right)}\right), \ldots, \ln \left(\lambda_{u} I^{\left(p_{u}\right)}\right. \\
& \left.\left.+H^{\left(p_{u}\right)}\right)\right\} S_{\left(J_{A}\right)}^{-1} T^{-1}
\end{aligned}
$$

with $T$ is the non-singular matrix which $A=T J_{A} T^{-1}, S_{\left(J_{A}\right)}$ is any commutative matrix with $J_{A}, J_{A}$ is the Jordan matrix of the matrix $A, \lambda_{i}$ is the characteristic value of the elementary divider $A, I$ is the identity matrix and $H^{(p)}$ is a square matrix which has 1 as a member of the first superdiagonal and 0 for other. The characteristic of matrix $A$ as domain of a natural logarithm function is a nonsingular square matrix with real positive characteristic values
\end{abstract}

Keywords: matrix, domain, natural logarithm

Sitasi: Kartika, D.E. 2018. Karakteristik Matriks sebagai Daerah Asal Suatu Logaritma. Matematika dan Pembelajaran, 6(1), 60-64. 


\section{PENDAHULUAN}

Fungsi logaritma merupakan salah satu bentuk fungsi yang tidak asing lagi dan sering dijumpai dalam bahasan di kalkulus. Salah satu fungsi logaritma yang akan dibahas dalam artikel ini adalah logaritma yang berbasis bilangan $e$ yang disebut logaritma asli, dan mempunyai lambang $\ln x$. Penulisan $\ln x$ dibaca logaritma asli dari $x$. Konsep logaritma asli ini diperlukan dalam pendefisian fungsi lainnya dalam kalkulus yaitu fungsi eksponen. Diketahui bahwa fungsi logaritma asli merupakan invers atau balikan dari fungsi eksponen. Selama ini fungsi logaritma, fungsi logaritma asli dan fungsi eksponen yang dipelajari di kuliah adalah fungsi yang hanya mempunyai daerah asal atau domain bilangan real.

Fungsi logaritma dalam domain bilangan real positif didefinisikan dengan

$$
y=\log _{a} x \leftrightarrow x=a^{y}
$$

dimana $a$ diandaikan bilangan positif bukan 1. Untuk fungsi logaritma asli maka $a=e$ (Purcell, 2009). Hal penting yang harus diperhatikan sebelum menghitung fungsi logaritma dengan daerah asal himpunan matriks adalah karakteristik suatu matriks yang dapat digunakan dalam fungsi logaritma khususnya fungsi logaritma asli.

Misalkan $F$ adalah suatu lapangan. $a_{i j} \in F, i=1, \ldots, m ; j=1, \ldots, n$,

maka bentuk $A=\left[\begin{array}{cccc}a_{11} & a_{12} & \ldots & a_{1 n} \\ a_{21} & a_{22} & \ldots & a_{2 n} \\ \ldots & \ldots & \ldots & \ldots \\ a_{m 1} & a_{m 2} & \ldots & a_{m n}\end{array}\right]$ disebut sebagai matriks atas $F$ dengan ukuran

$m \times n$. Matriks diatas juga dapat disimbolkan sebagai $A_{m \times n}=\left[a_{i j}\right]_{m \times n}$. Entri pada baris ke- $i$ dan kolom ke-j dari matriks $A$ disimbolkan dengan $a_{i j}$ atau $(A)_{i j}$

\section{HASIL DAN PEMBAHASAN}

Rumus fungsi logaritma asli dari matriks

$$
\begin{aligned}
& \ln A=X \\
& \quad=T S_{\left(J_{A}\right)}\left\{\operatorname { l n } \left(\lambda_{1} I^{\left(p_{1}\right)}\right.\right. \\
& \left.\quad+H^{\left(p_{1}\right)}\right), \ln \left(\lambda_{2} I^{\left(p_{2}\right)}+H^{\left(p_{2}\right)}\right), \ldots, \ln \left(\lambda_{u} I^{\left(p_{u}\right)}\right. \\
& \left.\left.\quad+H^{\left(p_{u}\right)}\right)\right\} S_{\left(J_{A}\right)}{ }^{-1} T^{-1}
\end{aligned}
$$

$T$ adalah matriks non-singular dimana $A=T J_{A} T^{-1}$

$S_{\left(J_{A}\right)}$ adalah sebarang matriks yang komutatif dengan $J_{A}$

$J_{A}$ adalah matriks Jordan dari matriks $A$

$J_{0}=\left[\begin{array}{ccccc}\lambda_{0} & 1 & 0 & \cdots & 0 \\ 0 & \lambda_{0} & 1 & \cdots & 0 \\ \vdots & & \ddots & \ddots & \vdots \\ \vdots & & & \ddots & 1 \\ 0 & \cdots & 0 & \cdots & \lambda_{0}\end{array}\right]=\lambda_{0} I^{(p)}+H^{(p)}$

$H^{(p)}$ adalah matriks berukuran $p \times p$ yang mempunyai 1 sebagai anggota pada 
superdiagonal pertama dan 0 untuk lainnya, yaitu $a_{i j}=1 \in H^{(p)}$ untuk $i=j \quad 1 ; j=$ $2,3, \ldots, p$ dan $a_{i j}=0$ untuk yang lainnya

$J=\left[\begin{array}{cccc}J_{1} & 0 & 0 & 0 \\ 0 & J_{2} & & \\ 0 & 0 & 0 & J_{u}\end{array}\right]=\left\{\lambda_{1} I^{\left(p_{1}\right)}+H^{\left(p_{1}\right)}, \lambda_{2} I^{\left(p_{2}\right)}+H^{\left(p_{2}\right)}, \ldots, \lambda_{u} I^{\left(p_{u}\right)}+H^{\left(p_{u}\right)}\right\}$

matriks $J$ disebut bentuk normal Jordan atau bentuk Jordan sederhana (Gantmacher, 1980)

$J_{i}$ disebut dengan Jordan Block dengan $\lambda_{i}$ adalah nilai karakteristik dari pembagi elementer A.

Rumus fungsi logaritma asli dengan daerah asal matriks beserta penjelasan tiap komponen diatas jelas membutuhkan matriks yang non-singular. Matriks non-singular sesuai dengan definisi berikut ini berhubungan dengan determinan suatu matriks.

Definisi 1 Suatu matriks persegi $A$ disebut matriks singular jika $|A|=0$, sebaliknya, suatu matriks persegi $A$ disebut matriks non-singular jika $|A| \neq 0$.

Definisi 2 Anggap $A$ adalah suatu matriks persegi dengan entri-entri bilangan real. Fungsi determinan dinyatakan dengan $\boldsymbol{d e t}$, dan mendefinisikan $\operatorname{det}(A)$ sebagai jumlah semua hasil kali dasar bertanda dari $A$.

det $: X$

$A \quad \operatorname{det}(A)$

dengan $X=\left\{A \quad A_{n \times h}\right\}$. Angka $\operatorname{det}(A)$ disebut determinan $A$ (Anton, 2000)

Dari definisi 2 terlihat bahwa matriks yang diperlukan adalah matriks persegi.

Definisi 3 Jika $A$ adalah sebuah matriks persegi, dan jika sebuah matriks $B$ yang berukuran sama bisa didapatkan sedemikian sehingga $A B=B A=I$ maka $A$ disebut mempunyai balikan dan $B$ disebut balikan (invers) dari $A$ (Anton, 2000). Invers dari $A$ dinotasikan dengan $A^{-1}$

Teorema 1 Suatu matriks persegi $A$ mempunyai invers jika dan hanya jika $A$ adalah matriks non-singular (Ayres, 1974)

Definisi 4 Dua matriks persegi $A$ dan $B$ disebut similar jika terdapat suatu matriks $R$ nonsingular sedemikian sehingga $B=R^{-1} A R$ (Ayres, 1974)

Teorema 2 Misalkan $A$ suatu matriks persegi, $\lambda$ adalah suatu nilai karakteristik dari $A$ jika dan hanya jika sistem persamaan $\left(\begin{array}{ll}\lambda I & A\end{array}\right) \boldsymbol{x}=\mathbf{0}$ mempunyai penyelesaian tak-trivial (Anton, 2000)

Teorema 3 Suatu matriks persegi $A$ mempunyai invers jika dan hanya jika $\lambda=0$ bukanlah suatu nilai karakteristik dari $A$ (Anton, 2000).

Definisi 5 Misalkan diberikan matriks persegi $A_{n \times n}$. Matriks karakteristik dari $A$ adalah $\lambda I \quad A$. Determinan dari matriks karakteristik $\lambda I \quad A$ adalah $|\lambda I \quad A|$ yang merupakan polinom dalam $\lambda$ dan disebut polinom karakteristik dari $A$ (Gantmacher, 1980) dan skalarskalar yang memenuhi $|\lambda I \quad A|=0$ disebut sebagai nilai karakteristik dari $A$.

Definisi 6 Ambil $\left(\begin{array}{ll}\lambda & \lambda_{0}\end{array}\right)^{p}$ sembarang pembagi elementer dari matriks persegi $A_{n \times n}$, dimana $\lambda_{0}$ adalah salah satu nilai karakteristik dari $A$ dan $p \neq 0$ adalah salah satu nilai dari $p_{1}, p_{2}, \ldots, p_{u}\left(p_{1}+p_{2}+\quad+p_{\mathrm{u}}=n\right)$, sehingga dapat dibentuk 


$$
J_{0}=\left[\begin{array}{ccccc}
\lambda_{0} & 1 & 0 & \cdots & 0 \\
0 & \lambda_{0} & 1 & \cdots & 0 \\
\vdots & & \ddots & \ddots & \vdots \\
\vdots & & & \ddots & 1 \\
0 & \cdots & 0 & \cdots & \lambda_{0}
\end{array}\right]=\lambda_{0} I^{(p)}+H^{(p)}
$$

dimana $I^{(p)}$ adalah matriks identitas dengan ukuran $p$ dan $H^{(p)}$ adalah matriks berukuran $p$ yang mempunyai 1 sebagai anggota pada superdiagonal pertama dan 0 untuk lainnya, yaitu $a_{i j}=1 \in H^{(p)}$ untuk $i=j \quad 1 ; j=2,3, \ldots, p$ dan $a_{i j}=0$ untuk yang lainnya. Jadi $J_{i}$ disebut dengan Jordan Block dengan $\lambda_{i}$ adalah nilai karakteristik dari pembagi elementer A.

Definisi 7 Misalkan diberikan pembagi elementer dari matriks $A$ yaitu

Maka

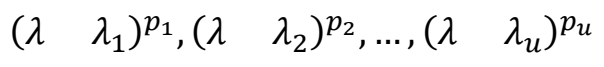

$$
J=\left[\begin{array}{cccc}
J_{1} & 0 & 0 & 0 \\
0 & J_{2} & & \\
0 & 0 & 0 & J_{u}
\end{array}\right]=\left\{\lambda_{1} I^{\left(p_{1}\right)}+H^{\left(p_{1}\right)}, \lambda_{2} I^{\left(p_{2}\right)}+H^{\left(p_{2}\right)}, \ldots, \lambda_{u} I^{\left(p_{u}\right)}+H^{\left(p_{u}\right)}\right\}
$$

dan matriks J disebut bentuk normal Jordan atau bentuk Jordan sederhana (Gantmacher, 1980).

Teorema 4 Setiap matriks persegi $A$ dengan ukuran $n \times n$ adalah similar dengan suatu matriks Jordan $J$, sehingga terdapat matriks non-singular $T$ sedemikian sehingga $A=$ TJT $T^{-1}$ (Gantmacher, 1980).

\section{KESIMPULAN DAN SARAN}

Berdasarkan hasil dan pembahasan dapat ditarik kesimpulan bahwa karakteristik suatu matriks A dapat menjadi daerah asal fungsi logaritma asli adalah sebagai berikut:

1. Matriks A berukuran $n \times n$ atau merupakan matriks persegi

2. Matriks A adalah matriks non-singular

3. Matriks A mempunyai nilai-nilai karakteristik real positif

Pembahasan tentang sifat-sifat logaritma asli yang juga berlaku dalam fungsi logaritma asli dengan daerah asal matriks dapat diteliti lebih lanjut, mengingat dalam artikel ini ini hanya membahas karakteristik matriks yang memenuhi dalam fungsi logaritma asli. Rumus umum untuk fungsi logaritma dengan daerah asal matriks juga belum diperoleh dan dikembangkan. Bagi para pembaca yang tertarik juga dapat mengembangkan bukti sifat $\ln A^{r}=r \ln A$ dengan $r \in$ yang tentunya membutuhkan kajian tentang akar dari suatu matriks. 
Kartika, D.E. 2018. Karakteristik Matriks sebagai Daerah Asal Suatu Fungsi Logaritma Matematika dan Pembelajaran, 6(1), 64 of 64

\section{DAFTAR RUJUKAN}

Anton, H. (2000). Dasar-dasar Aljabar Linear. Batam: Interaksara.

Ayres, F. J. (1974). Teori dan Soal-soal Matriks. Jakarta: Erlangga.

Gantmacher, F. (1980). The Theory of Matrices. New York: Chelsea Publishing Company. Purcell, E. J. (2009). Calculus. Illinois: Prenhall. 